\title{
LEARNING ENGLISH AS A FOREIGN LANGUAGE IN SOVIET TEN YEAR SCHOOLS
}

\author{
Horace W. Dewey \\ University of Michigan
}

\begin{abstract}
At the present time almost four million Soviet children take English as their foreign language in the ten-year school system (desiatiletka), which corresponds to our twelve-year pre-university program in the United States. Thousands start learning English at the age of eight, in the "second class" of elementary school. Since 1956 the Novosibirsk school system has been teaching German on an experimental basis to kindergarten youngsters, and similar experiments have been reported for English. Most Soviet pupils studying English, however, begin it in the "fifth class," which is roughly comparable to the sixth grade in American schools, and they continue with their English for a full six years. Few language teachers in our country will fail to be impressed by the sheer magnitude of the Soviet program. ${ }^{1}$ But what do we know of the aims and theories underlying this program, and what are the methods used to put them into effect?

It was my good fortune to visit some secondary-school English classes in Moscow and Leningrad in September, 1958. I was told by the school principals that language teachers are given considerable latitude in their choice of classroom methods. Nevertheless, there appears to be a degree of uniformity in Soviet language instruction which is unmatched in this country. The Minister of Education of any Soviet republic can supposedly tell, on a given day, just what lesson of which book is being

1ts magnitude is particularly impressive when compared with the teaching of Russian in American secondary schools. According to a survey made early in 1958, Russian was being taught in only sixteen high schools throughout the United States. Another survey disclosed that for every American studying Russian, roughly twenty-five hundred Soviet citizens were learning English. The teaching of Russian here is rapidly expanding at the present time.
\end{abstract}


covered, in any language class throughout the republic. 2 The current (1958-1959) program of foreign language instruction is set forth in such detail as to amount to a sort of linguistic sixyear plan, 3 and teachers are required to follow this plan closely. Until recently, few if any Soviet language teachers would have used the methods of a structural linguist, because structural linguistics was officially denounced as "formalism." One still looks in vain for the words "phoneme" or "morpheme" in the descriptive terminology of textbooks or the official program on language instruction. I never heard or saw any reference to such methods as "pattern practice" or the use of "substitution frames." It is doubtful that a Soviet teacher could get far trying to teach her pupils American English; textbook vocabularies list "lorry" but not "truck," "flat" but not "apartment," and the phonetic transcriptions indicate an unmistakable British pronunciation ("hockey" $=$ thoki; "pioneer" = paránia). A further measure of uniformity can be seen in the requirement that all pupils who have studied English in the ten-year schools must pass an English language examination prepared by the Ministry of Education before they can go on into higher education.

According to the plan, the overall requirements of the sixyear language course are to contribute in "solving the tasks of Communist upbringing and education"; to teach pupils to read and understand authentic foreign-language texts "of medium difficulty" with the help of a dictionary, and to "lay the bases for using the spoken language." 4 I was very interested to observe some of the ways in which these planned objectives were transformed into actual practice.

The total English vocabulary for the six years is two thousand six hundred words. 5 Although the compilers of the vocabulary have clearly followed some sort of frequency count in selecting most of these words, they have not overlooked their part in "solving the tasks of Communist upbringing and education." Thus, among the first three hundred fifty words (to be learned in the first year) one finds "America," "negro," and "South," along with "Soviet" and "collective farm." Almost all of these

2There is no All-Union (federal) Ministry of Education in the U.S.S.R. and there is considerable variety among the fifteen Soviet republics which make up the U.S.S.R. In a conversation with Y. G. Mamedaliev, President of the Academy of Sciences of the Azerbaijan S.S.R., I learned that about twenty percent of the secondary-school pupils there are learning Persian. The Deputy Minister of Education of the Uzbek Republic said that many pupils there are learning Chinese.

${ }^{3}$ Programma srednei shkoly na 1958-59 uchebnyi god. Inostrannye (Moscow, 1958), 53 pp.

$$
\begin{aligned}
& { }^{4} \text { Ibid., p. } 5 . \\
& 5_{\text {Ibid., }} \text { p. } 30 .
\end{aligned}
$$


words-even verbs and prepositions-are also represented by pictures or diagrams when they first appear.

The first thing that a Soviet pupil learns about the English language is that "in English there are forty-four sounds (twentyfour consonants and twenty vowels) which are transcribed by means of twenty-six written letters. "6 Immediately after this, he is informed that the English language has certain peculiar characteristics of its own when compared to Russian: for example, "English consonant sounds, as contrasted with Russian, are not softened..." Comparisons between English and Russian language phenomena continue throughout the six years of study.

The beginning pupil immediately starts learning the English alphabet, both printed and script. At the same time he is required to learn the international phonetic transcriptions of the forty-four English sounds, and is given such exercises as the following:

Find words in the English text containing the following sounds: [ae], [a], [i:], [ou],

or

Write English words with the following sounds:

$[\mathrm{t}\}],[\mathrm{k}],[\mathrm{s}],[\mathbf{z}],[\mathrm{z}],[\boldsymbol{\theta}]$.

Pupils are asked to read sets of minimal pairs, some of them presenting great difficulties for the native Russian speaker (pick, pig; bet, bed; fill, feel), or to read a list of English words and explain "in what way the underlined words fail to follow standard rules of English pronunciation: don't, dog, who, no, do, go, so, what, doesn't, rum, come." Pupils study English stress and intonation (called "melody" in the textbook) from passages marked with special symbols, such as the following, which deals with "Black Jimmy," a little American Negro boy:

/Black and /white children must/not/go to the /same school in the \South. /Jimmy and his $\mathcal{T}$ brothers go to INegro school. /Jimmy has tno / white friends. /After $\uparrow$ school he /plays Tonly with \black children. In the ISouth / white / children must / not / play with Jblack children. 7

${ }^{6}$ Z. M. Tsvetkova and Ts. G. Shpigel', English. Uchebnik angliiskogo iazyka dlia $V$ klassa (Moscow, 1958), p. 3.

7 Ibid. , pp. 123-124. 
At the same time, the first-year pupils must learn grammar rules and grammatical terminology. Since there is no article in Russian, the youngsters are early called on to explain the circumstances under which one says "give me $a$ map" or "give me the map" in English. Their grasp of English syntax is tested by asking them to

Make an English sentence from the following words: stands, the, in, table, the, room, middle, of, the.

They put singular sentences into the plural, or put affirmative sentences into the negative. They rewrite sentences, putting one line under the subject, and two lines under the predicate. They read the sentences "He skates well" and "Their skates are under the bench," then explain how one tells when the word skates is a noun and when it is a verb. In every instance they must not only be able to do the exercise, but explain the rules as well.

Some teachers told me that they were dissatisfied with this approach and hoped it would be revised. They felt that it was "too formal," that it burdened their pupils with unnecessary analysis and technical terminology at the expense of practice in spoken English. They pointed out that the large classes (those I visited averaged forty pupils, and I was given to understand that this was the normal, though certainly not the ideal size of language classes) made it very difficult to give each pupil his fair share of speaking practice.

But spoken English is by no means neglected. Teachers employ a variety of aural-oral methods. They require their pupils to do a great deal of reading aloud. They ask them questions in English on the text, or on general topics, and the pupils may reply in English. Pupils must be requested to "give English names to all the objects you can in this room," and are assigned English poems and tourist dialogues for memorization. A favorite device is to "talk about a picture" in English. One picture in the first-year textbook shows a boy and a girl on a sofa. The boy is reading a book. The girl is sitting with hands folded, listening to him. Questions based on this picture include the following:

Is Nick in the street?

Has Nick a book in his hands?

Is Nellie on the sofa?

Has Nellie a kitten in her hands?

In the second-year textbook there is a full-page picture of a schoolboy about to take a snapshot of his younger sister. The 
pupils are asked a total of seventy-four English questions about this picture 18 There are, as we mentioned earlier, no substitution frames, no exercises in pattern practice. In later years, pupils are asked to retell the story of the text in their own words, or to answer questions which require a statement of ideas pertaining to the text, but involving some vocabulary and constructions not found there: "What do you learn from this story about the attitude of American magazines to unknown writers?" 9

All teachers appear to favor mechanical aids for spoken English: pedagogical movies, records and tapes. These devices have been discussed in professional journals 10 and are used in the Foreign Languages Institute in Moscow, where many teachers receive a five-year training course in the language and culture of a specific country or area. But none of the secondary schools which I visited had yet acquired such mechanical aids.

Many teachers in this country disapprove of translation, particularly translation from the mother tongue into the foreign language, in early stages of language training. 11 In the Soviet Union, however, this method enjoys the official blessing of the Ministries of Education,12 and both translation from English into Russian and from Russian into English are used extensively from the outset. In the first years, to be sure, materials for translation are carefully selected so that word meaning and syntax of both languages "overlap" as much as possible. Typical sentences for translation from the mother tongue into English in the first year are as follows:

8I. A. Nelidova and L. R. Todd, English. Uchebnik angliiskogo iazyka dlia VI klassa (Moscow, 1958), pp. 93-95. (This is the third edition, printed in four hundred thousand copies l)

9I. A. Nelidova and L. R. Todd, English. Uchebnik angliiskogo iazyka dlia 10-ogo klassa (Moscow, 1958), p. 44 (seventh edition, 200,000 copies).

$10 \mathrm{~A}$ number of such articles have appeared in the journal Inostrannye iazyki $v$ shkole, which is entirely devoted to problems of foreign language instruction in the schools.

11 Many American teachers of Russian, for example, feel that it should be taught in controlled group oral practice, with initial emphasis on hearing and speaking. Later, it should be read, but without conscious translation. Still later, the pupil should be given written exercises, but should write only what he can already say correctly. See "Teaching Russian in American Secondary Schools," F. L. Bulletin, No. 59 (June, 1958), pp. 6-7.

12 See programma srednei shkoly na 1958-59 uchebnyi god, pp. 9-10. 


\section{LANGUAGE LEARNING VOL. IX, 1 \& 2}

This chair stands near the table.

Good pupils read very well.

Put this drum on that chair.

Another type of exercise which some American specialists regard as outmoded, but which is definitely encouraged in the Soviet Union, is dictation.13 One teacher I observed spent almost half an hour on dictation, with material selected for its difficulties in puncutation rather than orthography. Russianspeaking pupils have to unlearn their native habit of preceding the conjunction "that" with a comma, for example, as in the sentence "I knew that Boris was not at home."

Classroom procedure, to judge from what I witnessed, consists of various combinations of the methods discussed above. In a second-year language class which I visited in Moscow, the teacher was already conducting the class in English as far as possible. She started by asking individual pupils such questions as "Tell me what was your home work?" "Have you a book?" "What is your friend's name?" "Has Pete a cap?" and the like. When necessary, she would tell them "Don't hurry," or "That is almost right; try it again slowly." (She later told me that the children had been on edge because of my visit.) Next, she had the pupils translate a number of Russian sentences into English, orally and on the blackboard. Then she went into some detailed grammatical explanations, in Russian. After this, she had the entire class play a game of questions and answers in English: a girl pupil named Chekova asked the question "Where is your pen?" and called on a fellow-pupil named Oleshin to answer. Oleshin stood up and said, "My pen is on the desk." Oleshin then turned to a pupil named Matveev and asked, "Have you a dress?" Matveev, being a boy, emphatically denied the poses sion of a dress, to the general amusement of his classmates. Matveev then asked a girl named Prichishkina whether she had a dog. Prichishkina merely giggled. The teacher admonished her in English: "Don't laugh. Answer the question." And so it went. Then the pupils were asked, individually, to read a few lines in English from the textbook. The teacher, who spoke English with a very respectable British accent, kept close track of their pronunciation. The lesson closed with a five-minute explanation (in Russian) on the vagaries of the English plural. Soviet pedagogy distinguishes between two types of reading:

$13_{\text {Ibid. , p. } 11 .}$ 


\section{ENGLISH IN SOVIET TEN-YEAR SCHOOLS}

"synthetic" and "analytical. "14 Texts used for "synthetic" reading contain no unfamiliar words or grammatical constructions, while "analytical" reading introduces new words and constructions. "Synthetic" reading is practiced in class and as home work at all levels, whereas "analytical" reading is done only in class at first; in the later years of study, the pupil does more and more of it on his own.

In each of the first two years of English study (the "fifth" and "sixth" classes) there are one hundred and thirty-two contact hours. After that, there are ninety-nine English language contact hours per year. Phonetics, orthography and "rules of reading" 15 receive their greatest attention in the first two years, but are systematically reviewed and developed at the higher level.

As their study of English progresses, the pupils discover that several methods exist for translating English phrases into Russian: literal, descriptive and analogous. They are introduced to the complexities of English tenses, for example, the present perfect, the past indefinite and the past perfect, and must select the correct tense of the verbs "to be" or "to read" in such sentences as these:



They are confronted with the problem of multiple meaning, and, while there are generally fewer visual aids in the advanced textbooks, clever sketches illustrate the difference between the verbs "to say," "to tell," "to speak" and "to talk"--all of which may be expressed in the present tense by a single Russian verb. Pupils turn direct discourse passages into indirect discourse. They analyze single words, indicating whether they are simple, derivative or compound. In the last year of study they take up questions of lexicology and style: when is it preferable to say

14 Ibid., p. 9. For an example of "synthetic" reading, see the text in N. A. Egunova, E.G. Prokhorova, M. Ia. Rybkina, English. Uchebnik angliiskogo iazyka dlia VIII klassa (Moscow, 1958) p. 16, which is an adapted version of Dickens' "Our Mutual Friend".

15"'Rules of reading" explain English pronunciation in considerable detail. For example, "The combination of letters oo before $k$ is pronounced by the simple short vowel $[\mathrm{u}]$, for example: book. Before other consonants $o O$ is generally pronounced by the simple long vowel [u:], for example: school." Tsvetkova and Shpigel', op.cit., p. 57. 
"descend" and when "sit down"? When does one "commence" and when does one "begin"? What are metaphors, epithets, ellipses, metonymy and personification?

As the pupils advance, they do more and more reading. The textbooks at the higher level use English almost exclusively, even in the directions for exercises.16 Russian words appear only when necessary to explain idiomatic passages and vocabulary, or in translation exercises. The majority of reading selections are from English authors (Dickens, Scott, Wilde, Shakespeare, Thackeray, Jonson), but a few Americans (Twain, London, Dreiser) are represented. In the earlier years, these materials consist of adventure stories or factual essays, but when the pupils are in their teens the selections lean more toward social criticism and romance.

The final examinations in English language, taken by pupils at the end of their ten-year school program, consist of two parts. The first part involves reading and translating an unfamiliar English text, with dictionary. The second part is grammatical, and the pupils are required to answer such questions as the following:

Find in the text derived adjectives and indicate the suffixes in them. Determine the degrees of comparison of adjectives contained in the text and describe methods of forming them.

Find in the text the modal verbs. State their morphological peculiarities.

Find in the text a Gerund. Define the syntactical function of the Gerund in the text read. Show ways of translating into Russian. 17

It would be presumptuous on my part to attempt an evaluation of the positive features of English teaching in Soviet tenyear schools. I could not help being impressed-very favorably impressed-when one Vladimir Minin, aged 13, came up to me

${ }^{16}$ Beginning in the ninth class, a separate grammar (I. A. Gruzinskaia and E. B. Cherkasskaia, English Grammar) is used in conjunction with the textbook, which is E. B. Belova and L. R. Todd, English. Uchebnik angliiskogo iazyka dlia 9-go klassa (Moscow, 1956), 163 pp.

${ }^{17}$ See "Final Examinations in the Russian Ten-Year School," Information on Education Around the World (U.S. Department of Health, Education, and Welfare) No. 6 (October, 1958), pp. 20-22 for sample examination questions in English. 


\section{ENGLISH IN SOVIET TEN-YEAR SCHOOLS}

in the Leningrad post office and spoke with me in English for ten minutes. Vladimir admitted that he had recognized me as an American from my dress, and he wanted to know whether I had any American friends who might be interested in trading postage stamps with him. His English was good. When I complimented him on it, he said that he had been studying it "for several years" at his school.

But Soviet educators and administrators exhibit little satisfaction or complacency about the program of English instruction in the ten-year schools. On the contrary, there are reasons to believe that the whole system is about to be overhauled. I have already mentioned the criticisms I heard from individual teachers about excessive "for mality" and oversized classes. An instructor at the Moscow Foreign Languages Institute declared to me that students specializing in English there have to "start from scratch," although they have studied the language for six years in secondary school! Some teachers have carried their case to the press. What gives some of their complaints a certain significance is the fact that they appeared shortly before the announcement of plans to reform the entire Soviet educational system. A persistent theme in the reform discussions has been that the present educational program is impractical and "divorced from life," that its graduates are unprepared to take part in "socially-useful activity."18 According to one very interesting report, foreign language teaching is no exception: when they met young people from foreign lands at the Communist-sponsored World Youth Festival (held in Moscow in the summer of 1957), Soviet students who had studied English for six years or more found themselves unable to keep up a simple English conversation with their guests! "Everybody admits that our system of teaching foreign languages is unsuitable and does not justify itself," says the author of the report, himself a language teacher. "Yet no practical steps for modifying this system are in evidence... The difficulty is that the study of foreign languages here amounts simply to the cramming of individual

18See N. Khrushchev's proposals "On Strengthening the Ties of the Schools with Life and on Further Developing the Country's Public Education System," in Pravda, Sept. 20, 1958, p. 1, and the Resolution of the Plenary Session of the Communist Party Central Committee, adopted November 12, 1958, in Pravda, Nov. 14, 1958, p. 1 . The latter refers in its eighteenth section to the fact that "the study of foreign languages must be radically improved in schools all over the country". 
words and rules of grammar, with almost no practice in conversation... The Soviet Union's international ties are broadening, and our lag in the study of foreign languages is becoming intolerable." 19

I must confess that such attacks perplex me. Unless the schools which I was permitted to visit are on a much higher level than most in the Soviet Union, and therefore not genuinely representative of the quality of English language instruction there, my opinion would be that the Soviet system, whatever its defects, can hardly be said to "lag." Apparently some struggle is going on between various schools of theory and methodology, and we may witness some important changes of the system in the near future.

19 Komsomol'skaia pravda, May 14,1958, p. 3. The English translation of this revealing article (called "Improvement Urged in Language Teaching Methods") appears in The Current Digest of the Soviet Press, Vol. X, No. 28 (August 20, 1958), pp. 4-5. 